\title{
Bank Profits Rise Sharply
}

\author{
A Look ot the 1966 Income and Expenses of Eighth \\ Federal Reserve District Member Banks
}

\begin{abstract}
管 ROFITS AT MOST Eighth District member banks rose sharply in 1966. Profits after taxes at these banks totaled \$85 million last year, 14 per cent above 1965 . Major factors influencing the rise were an increase in the volume of loans and a higher rate of return on both loans and securities.
\end{abstract}

Net profits after taxes at member banks in the nation rose less rapidly, increasing 5 per cent. ${ }^{1}$ Gains in net current earnings (operating income less operating expenses) at banks in both the nation and district were similar, rising about 14 per cent in each case. The difference in the rates of gain in profits between district banks and banks in the country as a whole was almost entirely the result of a much larger increase in net losses, charge-offs, and transfers to valuation reserves at the latter banks.

During the past decade member bank profits in the district have risen at an 8.1 per cent rate and in the nation at a 7.9 per cent rate.

Relative to capital accounts, net profits after taxes in both the district and the nation have fluctuated in the comparatively narrow range of 8 to 10 per cent

\footnotetext{
${ }^{1}$ Preliminary estimates. Income and expense data for all member banks in the nation are published annually in the Federal Reserve Bulletin. The 1965 data for all member banks may be found in the June 1966 Bulletin and for all insured banks in the July 1966 issue. Income and expense data for all national banks are published in the Annual Report of the Comptroller of the Currency, while data for all insured banks are contained in the Annual Report of the Federal Deposit Insurance Corporation.
}

* Less than 0.05 . throughout the $1956-66$ period. They hit a peak of 10.2 per cent at district banks in 1960. After declining to 8.0 per cent in 1963 , the postwar low, net profits after taxes rebounded to 9.3 per cent of capital accounts in 1966 .

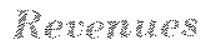

Operating revenues at district member banks totaled $\$ 503$ million in 1966 , an increase of 16 per cent from a year earlier (Table I). Revenues at these banks have risen at an average 9 per cent rate since 1956 . This growth reflects largely an increase in total

Table I

\section{REVENUES AND EXPENSES OF EIGHTH DISTRICT MEMBER BANKS}

\begin{tabular}{|c|c|c|c|c|c|}
\hline & \multicolumn{3}{|c|}{ Millions of Dollats } & \multicolumn{2}{|c|}{ Pet Cent Change } \\
\hline & \multirow[b]{2}{*}{1966} & \multirow[b]{2}{*}{1965} & \multirow[b]{2}{*}{1956} & & Annual Rat \\
\hline & & & & $1965-66$ & 1956.66 \\
\hline Revenue on loans.............. & 334.7 & 287.4 & 130.4 & 16.5 & 9.9 \\
\hline $\begin{array}{l}\text { Interest on securities } \\
\text { U.S. Government. }\end{array}$ & 75.7 & 69.6 & 43.5 & 8.8 & 5.7 \\
\hline Other $\ldots \ldots \ldots \ldots \ldots \ldots$ & 43.6 & 36.7 & 11.6 & 18.8 & 14.2 \\
\hline All other revenues,$\ldots \ldots \ldots \ldots$ & 48.8 & 41.7 & 23.6 & 17.0 & 7.5 \\
\hline Total operating revenues. . . & 502.8 & $\mathbf{4 3 5 . 4}$ & 209.1 & 15.5 & 9.2 \\
\hline Salaries, wages, and benefits.... & 118.9 & 109.0 & 59.5 & 9.1 & 7.1 \\
\hline Interest on time deposits........ & 138.6 & 114.2 & 16.9 & 21.4 & 23.4 \\
\hline Other expenses.$\ldots \ldots \ldots \ldots \ldots$ & 102.9 & 87.1 & 46.3 & 18.1 & 8.3 \\
\hline Total operating expenses. . . & 360.4 & 310.3 & 122.7 & 16.1 & 11.4 \\
\hline Net current earnings . . . . . & $\mathbf{1 4 2 . 3}$ & 125.1 & 86.4 & 13.7 & 5.1 \\
\hline $\begin{array}{l}\text { Recoveries, Iransfers from } \\
\text { reserves, and profits........ }\end{array}$ & 19.8 & 18.1 & 5.4 & & \\
\hline $\begin{array}{l}\text { Losses, charge-offs, and } \\
\text { tronsfers to reserves. }\end{array}$ & 44.7 & 36.9 & 27.1 & & \\
\hline Net ineome. . . . . . . . . & 117.4 & 106.3 & 64.7 & 10.4 & 6.1 \\
\hline Toxes on net income........... & 32.1 & 31,3 & 25.7 & 2.6 & 4.6 \\
\hline Nef income after taxes.... & 85.3 & 75.0 & 39.0 & 13.7 & 8.1 \\
\hline Cash diridends on common stock. & 32.9 & 30.9 & 17.1 & 6.5 & 6.7 \\
\hline $\begin{array}{l}\text { Interest on capital notes } \\
\quad \text { ond debentures } 1 \ldots \ldots \ldots\end{array}$ & 1.9 & 1.4 & * & & \\
\hline
\end{tabular}

${ }^{1}$ Includes small amount of cash dividends on preferred stock. 
assets, a shift from nonearning assets and relatively low yielding securities to higher earning assets, and a marked rise in the average level of interest rates.

Total resources of district member banks grew from $\$ 6.5$ billion in 1956 to $\$ 11$ billion in 1966, an average annual rate of 5.4 per cent. Earning assets of these banks grew somewhat more rapidly, from $\$ 4.9$ billion in 1956 to $\$ 8.6$ billion in 1966 , a 5.7 per cent rate. The slightly faster growth in earning than total assets reflects the fact that member banks placed an increasing proportion of their available funds in loans and investments. Nonearning cash balances were reduced from 23 per cent of assets in 1956 to 19 per cent in 1966. Reductions in reserve requirements facilitated this move.

In addition to the growth in total earning assets, banks have enhanced operating revenues by adjusting their portfolios to higher earning types of assets. Over the past decade, holdings of U. S. Government securities dropped from 29 to 16 per cent of assets (Chart 1). In contrast, loans rose from 40 per cent to 50 per cent of assets during this period. Meanwhile, "other" securities (mostly tax exempt issues of state and local governments) rose from 8 to 13 per cent.

Another factor tending to increase revenues of

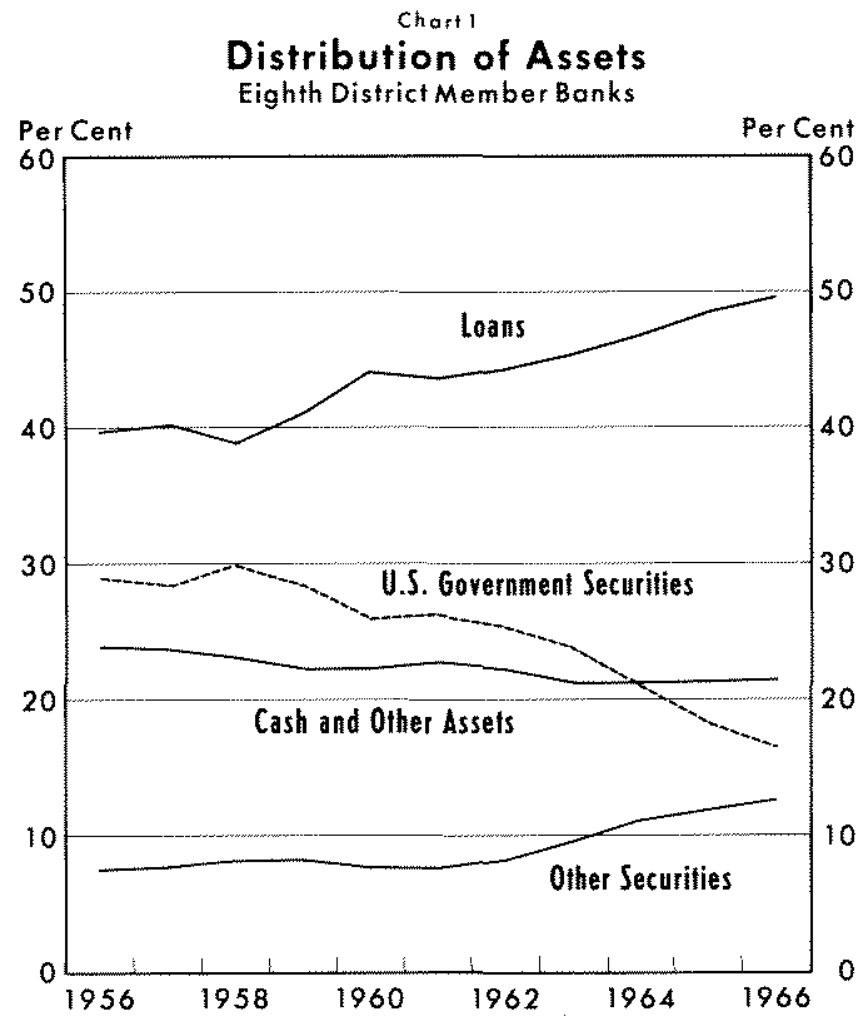

\section{Average Return on Securities and Loans \\ Eighth District Member Banks}

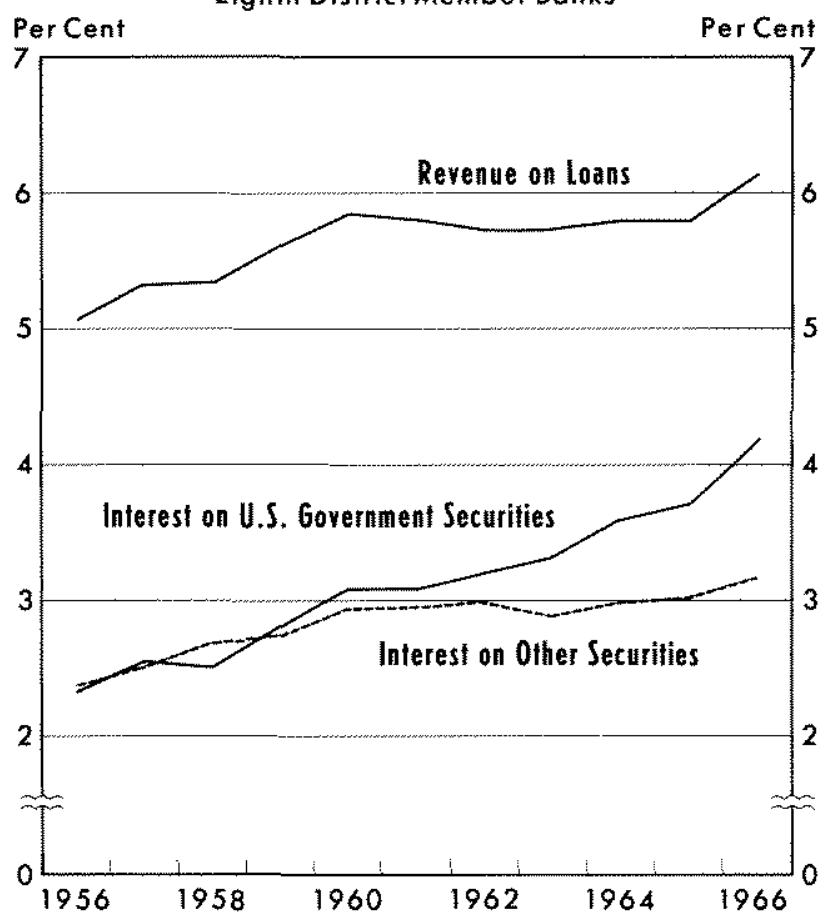

banks during the past decade has been the upward trend of interest rates. The average return on bank loans increased from about 5 per cent in 1956 to 6.1 per cent in 1966 (Chart 2). The average return on Government securities rose from 2.3 per cent to 4.2 per cent.

Growth in interest and charges on loans has accounted for a major portion of total bank revenue growth during the past decade. From $\$ 130$ million in 1956 , or 62 per cent of the total, revenue from loans rose to $\$ 335$ million, or 67 per cent of the total in 1966. Returns on loans increased at an average rate of 10 per cent during the period.

Although accounting for less than one-tenth of total revenues, interest on securities other than U.S. Governments has been the most rapidly growing revenue source. Interest on other securities rose from $\$ 12$ million in 1956 to $\$ 44$ million in 1966 , an average annual increase of 14 per cent.

In contrast to the rising importance of revenue from loans and other securities, revenue from U. S. Government securities has declined relative to the total since 1956. At that time, interest on Government securities was $\$ 44$ million, 21 per cent of total revenues, while in 1966 such revenue was $\$ 76$ million, 15 per cent of the total. From 1956 to 1966 such revenue 
Chart3

Net Losses or Profits on Securities and Loans

Eighth District Member Banks

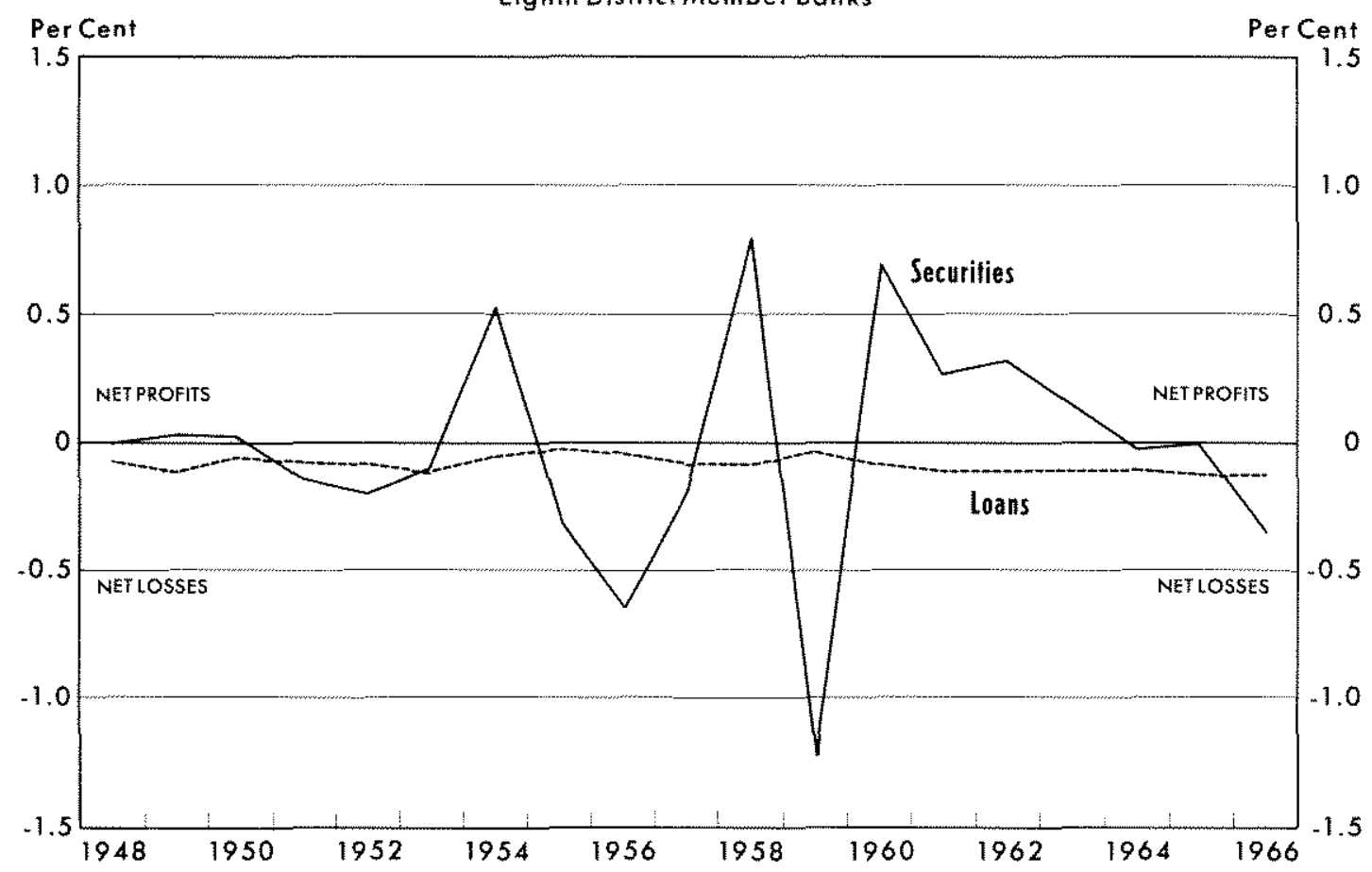

rose at an annual rate of 5.7 per cent.

Income from sources other than loans and investments has also grown during the past decade but contributed less to total revenues in 1966 than in earlier years. Service charges on deposit accounts, trust department earnings, and other receipts have risen at an average annual rate of 7.5 per cent since 1956 . These items accounted for 12 per cent of total revenue in 1956 compared with about 10 per cent in 1966.

\section{Experases}

Operating expenses of district member banks total. ed $\$ 360$ million in 1966, up 16 per cent from the previous year (Table 1). Interest paid on time and savings deposits, up 21 per cent, was the most rapidly rising major expense item. Wages, salaries, and employee benefits rose 9 per cent, and all other expenses increased 18 per cent.

Since 1956 operating expenses of member banks in the district have risen from $\$ 123$ million to $\$ 360$ million, an annual rate of 11.4 per cent. Reflecting both the sharply rising volume of time and savings deposits and the upward trend in interest rates on these accounts, interest expense was the major factor in the overall increase.

Interest expense rose from $\$ 17$ million in 1956 to
$\$ 139$ million in 1966 , an average annual rate of 23 per cent. This is in sharp contrast with the immediate postwar decade when such expense rose at a 10 per cent rate. In 1946 cash and Government securities accounted for almost three-fourths of assets at member banks in the district. This liquidity enabled banks to meet most of their loan demand through shifts in portfolio holdings and growth in reserves during the 1946 to 1956 period. Banks accepted time and savings deposits at relatively moderate interest rates.

Since 1956, however, with the opportunities for profitable lending and with a minimum of other assets for shifting into loans, banks have bid aggressively for time and savings deposits. Both the volume of such deposits and the average rate paid have increased rapidly. Time and savings deposits rose at a rate of 3.7 per cent per year from 1946 to $1956 \mathrm{com}$ pared with rates of 7 per cent from 1956 to 1960 and 15 per cent since 1960 . The average rate of interest paid on time and savings deposits rose from 0.8 per cent in 1946 to 1.36 per cent in $1956,2.37$ per cent in 1960 , and 3.77 per cent in 1966 .

Other major expense items have increased but less rapidly than interest expense during the past decade. Salaries, wages, and fringe benefits rose at an average annual rate of 7 per cent, and all other expenses at an 8 per cent rate. 


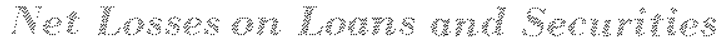

Net losses on loans (exclusive of transfers between undivided profits and valuation reserves) totaled $\$ 7$ million in 1966, an increase of 8 per cent from the previous year. The ratio of net losses on loans to total loans was 0.13 per cent, unchanged from a year earlier. Although this is a reasonably low rate, it is slightly greater than the average level of the 1950 's.

Net losses on securities at district member banks in 1966 totaled $\$ 11$ million compared with net profits of $\$ 0.3$ million in 1965. The large losses resulted from the combination of an exceptionally strong loan demand and depressed security prices during the past year. To meet the rapidly rising loan demand, banks found it profitable to liquidate some of their security holdings at the depressed price levels prevailing during most of the year. The sale of some securities may also have been motivated by tax considerations. Banks may deduct capital losses resulting from security sales from ordinary income taxed at a maximum rate of 48 per cent. By selling some of their securities when prices decline and simply buying others, banks obtain expected future capital gains which are taxed at a maximum 25 per cent rate. In this mamer, banks trade ordinary income for future capital gains which are taxed at a much lower rate.

The ratio of net losses on securities to total securities was 0.35 per cent in 1966 . The ratio of losses or gains on securities to total securities fluctuates considerably from year to year (Chart 3). During the past decade it has ranged from a net gain of 0.8 per cent in 1958 to a net loss of 1.2 per cent in 1959 .

Although net losses on loans and securities combined were greater than in other recent years (except 1956 and 1959), banks were able to show a net addition to total valuation reserves. These reserves at the end of 1966 were $\$ 103$ million, 4.4 per cent above a year earlier. In comparison, valuation reserves rose at a 10 per cent rate from 1956 to 1966. Such reserves, while not included in capital accounts, serve much the same purpose. They are in a sense a form of hidden capital in banks. Loan and security valuation reserves at district member banks are currently about 11 per cent of the volume of total capital accounts.

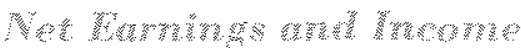

Net current earnings of member banks in the district totaled $\$ 142$ million in 1966 , an increase of 14 per cent from a year earlier (Table I). Since 1956 net current earnings have risen at a 5 per cent annual rate. The result of all adjustments for net losses, charge- offs, and transfers to valuation reserves was a reduction in net income before taxes of $\$ 25$ million in 1966 compared with a reduction of $\$ 19$ million in 1965 .

Net income before taxes amounted to $\$ 117$ million in 1966,10 per cent above the previous year. Income taxes rose only 2.6 per cent, reflecting both the greater losses on security sales and the greater tax-exempt income on municipal securities.

Net profits after taxes totaled $\$ 85$ million in 1966 , an increase of 14 per cent from 1965. Since 1956, aftertax profits at district member banks has risen at an 8 per cent rate. Net profits relative to capital accounts in 1966 were 9.3 per cent, up from 8.8 per cent a year earlier. During the past decade the ratio of profits to capital at member banks in both the district and the nation has fluctuated from 8 to 10 per cent (Chart 4). Although average profits in other businesses over this period have generally been higher, profits at banks have shown greater stability. Comparisons of the rates of return on capital between banks and other businesses, however, may be somewhat misleading. The primary purpose of capital in a nonfinancial business is to provide physical plant and equipment. In banking these requirements are usually quite modest relative to total resources. The primary function of capital in banking is to provide safety, or protection against unexpected losses and shrinkage in value of assets.

\section{Chast 4 \\ Net Profits and Dividends as a Per Cent of Total Capital}

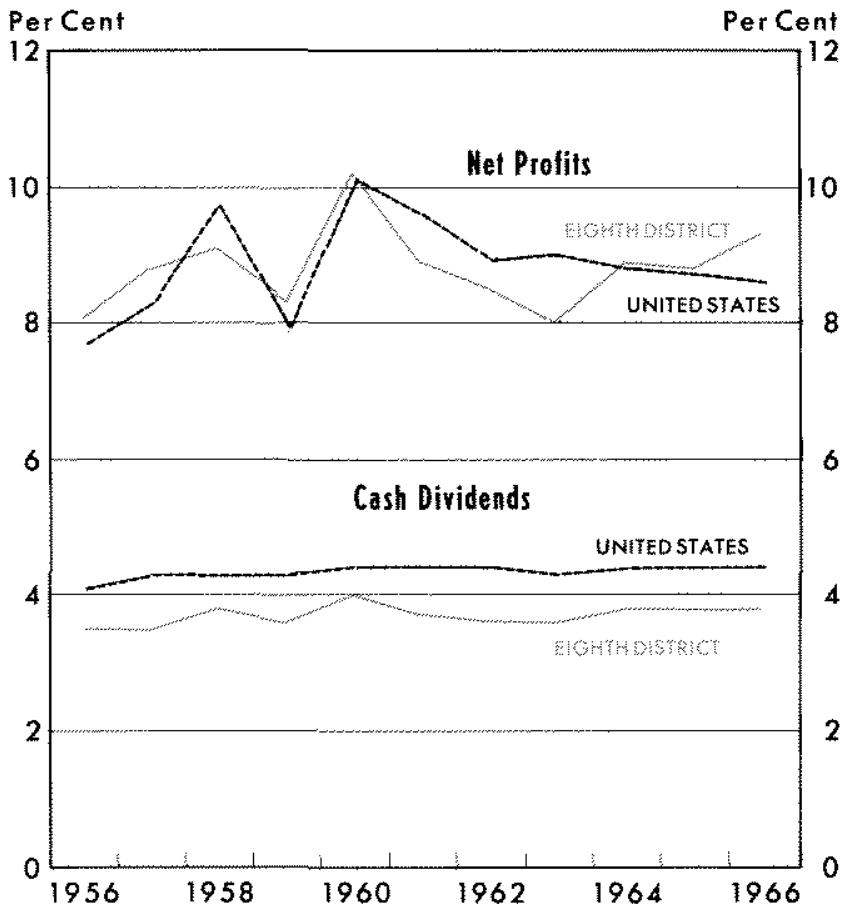




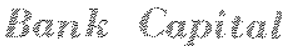

Determining the optimum amount of capital for a bank is not an easy task. Stockholders generally prefer to have as little as possible in order that profits on invested funds (which come primarily from investing deposits) will be maximized. Depositors, particularly those with large accounts, prefer to have as much capital cushion for protection as possible. With capital in banking designed to serve this somewhat unique function of protecting depositors, the amount of capital invested is heavily infuenced by regulation and supervision. As a result, the adequate capital requirements set for banks for safety purposes may sometimes be at the expense of higher returns on capital.

Total capital accounts of district member banks were $\$ 912$ million in 1966 , an increase of 6.8 per cent from 1965. Since 1956, capital of these banks has risen at a 6.5 per cent rate. In the late 1950 's capital was rising somewhat more rapidly than either total deposits or total assets. As a result the capital-toassets and capital-to-deposits ratios both rose (chart 5). Since 1960 these ratios have shown very little net change. In contrast the ratio of capital to risk assets (total assets less Government securities and cash) has declined from about 16 per cent, prevailing in the 1956-60 period, to 13 per cent in 1966.

Traditionally banks have raised nearly all of their capital through the issue of common stock and retained earnings. In several recent years a significant portion of new capital was raised through the sale of capital notes and debentures. During the 1963-66 period district member banks sold $\$ 42$ million of such debt capital. This represented about 24 per cent of

\section{Total Capital}

as a Per Cent of Assets and Deposits

Eighth District Member Banks

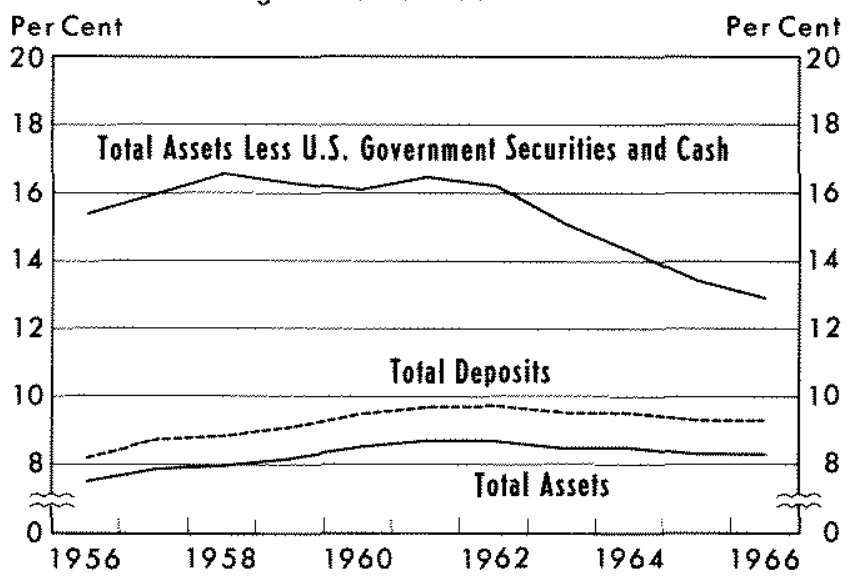

the net addition to capital accounts during these years.

Somewhat over $\$ 20$ million of capital notes and debentures were sold by district member banks in 1963, the first year of sizable sales of such capital. During 1966 such sales totaled slightly under $\$ 1$ million compared with $\$ 14.8$ million in 1965 (Table II). The lower level of sales in 1966 is probably indicative of the unwillingness of banks to make longterm capital commitments of this type, given the relatively high market interest rates prevailing during the year.

Table II

CAPITAL NOTES AND DEBENTURES ${ }^{1}$

EIGHTH DISTRICT MEMBER BANKS

(Thousands of Dollars)

\begin{tabular}{cccc}
$\begin{array}{c}\text { Sold during } \\
\text { year }\end{array}$ & $\begin{array}{c}\text { Retired during } \\
\text { year }\end{array}$ & $\begin{array}{c}\text { Outstanding of } \\
\text { end of yeor }\end{array}$ \\
\cline { 2 - 3 } 1962 & - & - & 200 \\
1963 & 20,250 & - & 20,450 \\
1964 & 6,200 & - & 26,650 \\
1965 & 14,750 & 50 & 41,350 \\
1966 & 950 & 150 & 42.150
\end{tabular}

${ }^{1}$ Includes small amount of preferred stock.

Interest on capital notes and debentures at district member banks totaled $\$ 1.9$ million in 1966 , an increase of 35 per cent from a year earlier. The average rate of interest paid on debt capital was 4.6 per cent.

\section{Crong}

The year 1966 was a profitable one for most member banks in the Eighth District. Net operating earnings rose 14 per cent, nearly triple the average rate of the past decade ( 5 per cent per year). After adjustments for net losses, charge-offs, and transfers to valuation reserves, net income before taxes rose 10 per cent from the previous year. Despite the sharp drop in security prices and substantial losses on security sales, bank earnings were sufficient to provide small net additions to loan and security valuation reserves. The increase in capital and valuation reserves combined was 6.6 per cent last year compared with a 9 per cent increase during 1965 and a 7 per cent rate of increase from 1956 to 1966 .

Net profits after taxes at district member banks rose 14 per cent from 1965 to 1966 compared with an average growth of 8 per cent per year during the past decade. Net profits relative to capital accounts in 1966 were 9.3 per cent, up from 8.8 per cent a year earlier and a postwar low of 8.0 per cent in 1963 . 